\title{
Clinical Reasoning: A 47-Year-Old With Headache, Vertigo, and Double Vision
}

Jessica Frey, MD, Joshua Kramer, MD, Rudolph Castellani, MD, and Shitiz Sriwastava, MD

Neurology ${ }^{\circledR}$ 2021;97:e535-e539. doi:10.1212/WNL.0000000000012138
Correspondence

Dr. Frey

jess.el.frey@gmail.com

\section{Section 1}

A 47-year-old man with a history of isolated, severe, recurrent episcleritis of the left eye, on adalimumab and methotrexate for the past 2 years, presented with acute vertigo. Two days later, in addition to ongoing vertigo, he developed a mild headache behind his right eye, which intensified over 5 days and worsened with Valsalva maneuver and when lying down. He denied nausea, vomiting, light or sound sensitivity, or a history of headaches. On the fifth day of symptoms, he developed double vision, which persisted regardless of the severity of the headache and was worse when looking to the right. On examination, vital signs were normal without evidence of fever. Extraocular movements were notable for mildly restricted gaze of the right eye when looking toward the right side. Pupils were reactive, ophthalmoscopic examination did not show papilledema, and finger to nose test was normal. Mental status, strength, sensation, and reflexes were normal.

\section{Questions for Consideration:}

1. Based on the presenting symptoms, what is on the differential?

2. What studies would you obtain to help narrow the differential diagnosis?

GO TO SECTION 2 


\section{Section 2}

In order to differentiate between primary and secondary headaches, the SNNOOP10 mnemonic is helpful: systemic symptoms, neoplasm history, neurologic symptoms, onset that is abrupt, older age ( $>65$ years), pattern change, positional quality, precipitation by Valsalva, papilledema, progressively atypical symptoms, pregnancy, painful eye, posttraumatic, pathology of the CNS, and painkiller overuse are red flags for secondary headaches. ${ }^{1}$ This patient's abrupt onset, precipitation by Valsalva, and associated neurologic symptoms indicate a secondary cause of the headache. The right-sided gaze palsy indicates cranial nerve involvement, which can localize anywhere along the course of the abducens nerve, including the brainstem, subarachnoid space, cavernous sinus, or superior orbital fissure. A broad differential for these secondary causes includes vascular events such as stroke, infectious processes such as meningitis, inflammatory processes such as neurosarcoidosis or vasculitis, traumatic injuries, and neoplastic causes such as a brain tumor or leptomeningeal spread. The history was negative for clotting disorders, trauma, cancer, or known autoimmune conditions.

An MRI revealed dural thickening in the region of the right tentorium and enhancement of the meninges in the cerebellopontine angle (figure). There was no parenchymal involvement and vessel imaging was normal. The patient underwent a lumbar puncture with a normal opening pressure, which revealed 3 nucleated cells (lymphocyte predominant), 1 red blood cell, protein $80 \mathrm{mg} / \mathrm{dL}$, and glucose $88 \mathrm{mg} / \mathrm{dL}$. A week after his initial symptoms, he developed a right peripheral facial nerve palsy. He was also evaluated by an ear, nose, and throat physician and determined to have rightsided sensorineural hearing loss.

\section{Questions for Consideration:}

1. Based on the imaging and multiple cranial neuropathies, what would be highest on your differential?

2. What additional testing would help reach a diagnosis?

Figure Imaging and Histopathologic Characteristics of Granulomatosis With Polyangiitis (GPA)

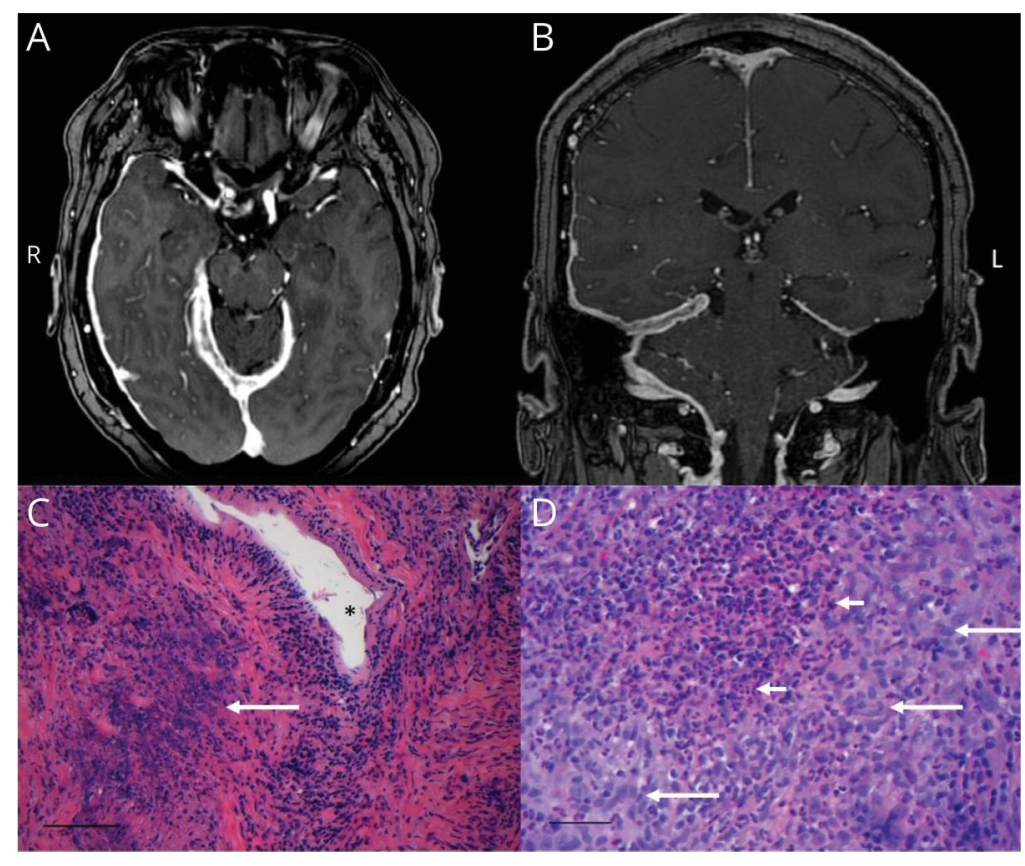

(A) Axial and (B) coronal view of gadolinium-enhanced MRI of the brain demonstrates dural thickening and enhancement of the right tentorium and cerebellopontine angle. (C) Histopathologic sections demonstrate the lumen of a small blood vessel, as noted by the asterisk. Note the infiltration of the blood vessel wall by chronic inflammatory cells. The arrow indicates a focus of necrosis with basophilic debris (scale bar $=100 \mu \mathrm{m})$. (D) Collections of extravascular epithelial and multinucleated histiocytes are present (long arrows), along with infiltration by neutrophils (short arrows), characteristic of granulomatosis with polyangiitis (scale bar $=50 \mu \mathrm{m}$ ). 


\section{Section 3}

There are many diagnostic possibilities in a patient with multiple cranial nerve palsies and dural thickening and enhancement. Although there was no pleocytosis in the CSF, immunosuppressed patients may not be able to mount an immune response to underlying infection and thus infectious processes such as neurotuberculosis, Lyme disease, and fungal infections should be considered. A repeat lumbar puncture a week after symptom onset demonstrated $6 \mathrm{nu}$ cleated cells ( $78 \%$ lymphocytes), 16 red blood cells, protein $114 \mathrm{mg} / \mathrm{dL}$, and glucose $91 \mathrm{mg} / \mathrm{dL}$. Testing for specific viral, fungal, and bacterial infections in the CSF all returned negative.

Cancer accounts for $30 \%$ of cases presenting with multiple cranial neuropathies. ${ }^{2}$ Although there was no compressing tumor, leptomeningeal spread is also a possibility. Lymphoma is an important consideration, especially in immunocompromised patients. However, CSF cytology was negative for malignant cells, including lymphoma, making this a less likely diagnosis.

Two of the most common inflammatory conditions causing multiple cranial neuropathies and dural thickening include neurosarcoidosis and vasculitis. Serum angiotensin-converting enzyme (ACE), CSF ACE, and CSF interleukin-2 receptor antibody were negative and there was no hilar adenopathy, making neurosarcoidosis less likely. Serum laboratory studies for vasculitis that were negative included rheumatoid factor, hepatitis B, hepatitis C, HIV, immunoglobulin G4, anti-Smith antibodies, anti-Ro antibodies, anti-La antibodies, and anti-double stranded DNA antibodies. CSF paraneoplastic panel was negative. Serum perinuclearstaining antineutrophil cytoplasmic antibody (p-ANCA) and myeloperoxidase (MPO) antibodies were negative. Serum cytoplasmic-ANCA (c-ANCA) and proteinase 3 (PR3) antibodies were positive, supporting a diagnosis of PR3-associated vasculitis.

Adalimumab and methotrexate are not standard treatments for episcleritis. Recurrent episcleritis warrants further investigation for systemic causes. In retrospect, the patient was likely started on this immunosuppressive regimen due to suspicion that his recurrent episcleritis was part of a larger autoimmune condition, which turned out to be PR3associated vasculitis that had not yet progressed to involve other organ systems. Given the results of the above tests, the patient was started on methylprednisolone with resolution of his headache and improvement in his vertigo and facial nerve palsy.

\section{Questions for Consideration:}

1. How would you make a definitive diagnosis?

2. What are the treatment considerations for PR3-associated vasculitis?

\section{GO TO SECTION 4}




\section{Section 4}

Biopsy of affected tissue leads to definitive diagnosis. Biopsy of the dura overlaying the right tentorium revealed calvarial dura with mixed inflammation. There was infiltration of blood vessel walls by chronic inflammatory cells, scattered foci of geographic necrosis containing basophilic debris, foci of neutrophilic inflammation, and extravascular epithelioid and multinucleated histiocytes (figure). Based on the history, examination, serum markers, and histopathology, the patient was formally diagnosed with hypertrophic pachymeningitis (HP) associated with granulomatosis with polyangiitis (GPA).

The patient was started on an induction regimen of rituximab $375 \mathrm{mg} / \mathrm{m}^{2}$ weekly over 4 weeks. A few months later, there was minimal clinical improvement and radiographic evidence of worsening dural thickening and enhancement. Cyclophosphamide in combination with prednisone is the standard therapy for patients who develop worsening pachymeningeal thickening and refractory clinical symptoms. ${ }^{3}$ Therefore, the patient was started on an induction regimen of cyclophosphamide $500 \mathrm{mg} / \mathrm{m}^{2}$ monthly for 6 months in combination with $60 \mathrm{mg}$ prednisone daily. His symptoms have significantly improved since starting this regimen. Once disease remission is achieved, the patient will be switched to azathioprine as maintenance therapy.

\section{Discussion}

GPA, previously known as Wegener granulomatosis, is an autoimmune vasculitis that affects small to medium-sized vessels, including upper respiratory tract, lower respiratory tract, and kidneys. ${ }^{4}$ The draft classification criteria for GPA consists of the following characteristics, each weighted by a number: bloody nasal discharge $(+3)$, cartilaginous involvement $(+2)$, conductive or sensorineural hearing loss $(+1)$, pauci-immune glomerulonephritis $(+1)$, c-ANCA or PR3 antibody (+5), p-ANCA or MPO antibody $(-1)$, eosinophil count $\geq 1 \times 10^{9} / \mathrm{L}(-4)$, granulomas or giant cells on biopsy $(+2)$, nodules on chest imaging $(+2)$, and paranasal sinus inflammation $(+1) .^{5}$ A score of $\geq 5$ carries a $93 \%$ sensitivity and $94 \%$ specificity for a diagnosis of GPA. ${ }^{5}$

Neurologic complications of GPA occur in $22 \%-54 \%$ of cases, ${ }^{4}$ and are a result of different histopathologic patterns, including vasculitis of the small vessels of the brain or granulomatous invasion from extracranial sites. ${ }^{6}$ Historically, peripheral neuropathy was the most common neurologic complication, with CNS involvement reported in only $8 \%$ of cases. ${ }^{7}$ With the advent of modern imaging, however, it has become easier to detect CNS involvement of GPA.

$\mathrm{HP}$ is a condition of chronic fibrous inflammation of the dura mater that is largely idiopathic, but may be immune-mediated. ${ }^{4} \mathrm{HP}$ accounts for $33 \%$ of the neurologic complications of GPA and may be a presenting feature in as many as $60 \%$ of cases. ${ }^{6}$ The most common clinical feature of HP is headache ( $73 \%$ of cases), followed by cranial neuropathies $(50 \%$ of cases), with cranial nerves II, V, VI, and VII as the most common cranial nerves affected. ${ }^{6,7}$ Seizures, ataxia, and encephalopathy may also be complications of GPA-related HP. ${ }^{7,8}$ However, GPA-related HP is a challenging diagnosis because patients have fewer systemic manifestations, and thus vasculitis is often not initially considered. In addition, the clinical presentation mimics other diseases, including neurosarcoidosis, spontaneous intracranial hypotension, infectious meningitis, Erdheim-Chester disease, immunoglobulin G4related disease, and idiopathic pachymeningitis.

c-ANCA/PR3 is highly specific for GPA, although it can be positive in other vasculitides. ${ }^{9}$ In addition to its use as a diagnostic tool, titers of PR3-ANCA correlate with disease activity, with a rise in PR3 indicating relapse. ${ }^{9}$ MPO-ANCA is not specific for GPA but up to $20 \%$ of patients with GPArelated HP are positive for MPO. ${ }^{4}$ These patients may actually have a distinct clinical entity known as CNS-limited GPA, with lesions restricted to the dura mater and upper airways. ${ }^{4}$ Whereas these serum markers help support a diagnosis of GPA, biopsy of affected tissue is often needed to confirm the diagnosis.

Early treatment with cyclophosphamide or rituximab in combination with glucocorticoids leads to improved clinical outcome and lower rate of relapse. ${ }^{4,6}$ Patients with pachymeningitis are more refractory to rituximab and patients with positive PR3 antibodies have higher annual relapse rates. ${ }^{6}$ In our patient with both of these features, early diagnosis and initiation of treatment was crucial to optimizing his clinical outcome. This case highlights several aspects of the neurologic features of GPA-related HP, including the presenting symptoms of $\mathrm{HP}$, diagnostic considerations including c-ANCA/PR3 antibodies and biopsy, and the importance of early recognition and treatment with immunomodulatory therapy.

\section{Study Funding}

The authors report no targeted funding.

\section{Disclosure}

The authors report no disclosures relevant to the manuscript. Go to Neurology.org/N for full disclosures.

\section{Appendix Authors}

\begin{tabular}{lll}
\hline Name & Location & Contribution \\
\hline $\begin{array}{l}\text { Jessica Frey, } \\
\text { MD }\end{array}$ & $\begin{array}{l}\text { West Virginia } \\
\text { University, } \\
\text { Morgantown }\end{array}$ & $\begin{array}{l}\text { Conceptualization, writing of the } \\
\text { first draft, major revisions }\end{array}$ \\
\hline $\begin{array}{l}\text { Joshua } \\
\text { Kramer, MD }\end{array}$ & $\begin{array}{l}\text { West Virginia } \\
\text { University, } \\
\text { Morgantown }\end{array}$ & Conceptualization, major revisions \\
\hline
\end{tabular}




\section{Appendix (continued)}

\begin{tabular}{lll}
\hline Name & Location & Contribution \\
\hline $\begin{array}{l}\text { Rudolph } \\
\text { Castellani, } \\
\text { MD }\end{array}$ & $\begin{array}{l}\text { West Virginia } \\
\text { University, } \\
\text { Morgantown }\end{array}$ & Conceptualization, major revisions \\
\hline $\begin{array}{l}\text { Shitiz } \\
\text { Sriwastava, } \\
\text { MD }\end{array}$ & $\begin{array}{l}\text { West Virginia } \\
\text { University, }\end{array}$ & Conceptualization, major revisions \\
\hline
\end{tabular}

\section{References}

1. Do TP, Remmers A, Schytz HW, et al. Red and orange flags for secondary headaches in clinical practice. Neurology. 2019;92(3):134-144.
2. Pobasco JC, Munchel AT, McArthur JC, Blakeley JO. Clinical reasoning: multiple cranial neuropathies in a young man. Neurology. 2013;80(6):e60-e66.

3. Geetha D, Kallenberg C, Stone JH, et al. Current therapy of granulomatosis with polyangiitis and microscopic polyangiitis: the role of rituximab. J Nephrol. 2015;28(1): 17-27.

4. Choi HA, Lee MJ, Chung CS. Characteristics of hypertrophic pachymeningitis in patients with granulomatosis with polyangiitis. J Neurol. 2017;264(4):724-732.

5. Robson JC, Grayson PC, Ponte C, et al. OP0021 Draft classification criteria for the ANCA associated vasculitides. Ann Rheum Dis. 2018;77:60-61.

6. Smolenska Z, Masiak A, Zdrojewski Z. Hypertrophic pachymeningitis as an important neurological complication of granulomatosis with polyangiitis. Reumatologia. 2018; 56(6):399-405.

7. Nishino H, Rubino FA, DeRemee RA, Swanson JW, Parisi JE. Neurological involvement in Wegener's granulomatosis: an analysis of 324 consecutive patients at the Mayo Clinic. Ann Neurol. 1993;33(1):4-9.

8. Drachman DA. Neurologic complications of Wegener's granulomatosis. Arch Neurol. 1963;8:145-155.

9. Shiotani A, Mukobayashi C, Oohata H, et al. Wegener's granulomatosis with dural involvement as the initial clinical manifestation. Intern Med. 1997;36(7):514-518. 


\section{Neurology}

Clinical Reasoning: A 47-Year-Old With Headache, Vertigo, and Double Vision Jessica Frey, Joshua Kramer, Rudolph Castellani, et al.

Neurology 2021;97;e535-e539 Published Online before print April 30, 2021

DOI 10.1212/WNL.0000000000012138

This information is current as of April 30, 2021

Updated Information \& Services

References

Subspecialty Collections

Permissions \& Licensing

Reprints including high resolution figures, can be found at: http://n.neurology.org/content/97/5/e535.full

This article cites 9 articles, 2 of which you can access for free at: http://n.neurology.org/content/97/5/e535.full\#ref-list-1

This article, along with others on similar topics, appears in the following collection(s):

Secondary headache disorders

http://n.neurology.org/cgi/collection/secondary_headache_disorders Vasculitis

http://n.neurology.org/cgi/collection/vasculitis

Vertigo

http://n.neurology.org/cgi/collection/vertigo

Information about reproducing this article in parts (figures,tables) or in its entirety can be found online at:

http://www.neurology.org/about/about_the_journal\#permissions

Information about ordering reprints can be found online:

http://n.neurology.org/subscribers/advertise

Neurology ${ }^{\circledR}$ is the official journal of the American Academy of Neurology. Published continuously since 1951, it is now a weekly with 48 issues per year. Copyright @ 2021 American Academy of Neurology. All rights reserved. Print ISSN: 0028-3878. Online ISSN: 1526-632X.

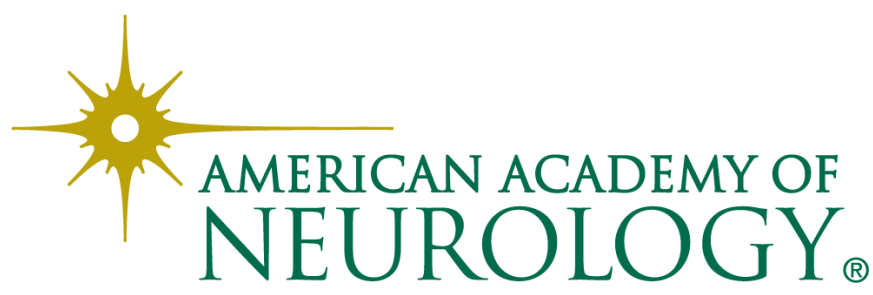

